\title{
The practicalities of managing cultivar change
}

\author{
DAVE ALLEN \\ Seed Grower, P.O. Box 335, Ashburton
}

\begin{abstract}
Ten years experience from trial-and-error plus some advice, has led to the development of successful base management systems for white clover cultivar-change. These systems are capable of modification according to site and season to maximise seed returns and have reached the point where white clover is now my safest crop. This paper considers crop management requirements necessary from the 'change' decision, some years before inception, through to harvested seed yield.
\end{abstract}

Keywords: crop management, cultivar-change requirements, harvest, seed production, sowing technology, Trifolium repens L., white clover

\section{Introduction}

Ten years experience in growing white clover (Trifolium repens L.) 'cultivar-change' seed crops has led to the development of an awareness of total dedication to key decisions in terms of consistent success within the change process, followed by long-term financial gains, compared with growing 'Grasslands Huia' white clover.

\section{MAF Quality Management Certification require- ments}

What do the MAF certification requirements mean and how are they going to affect 'change-crop' management? Many of my decisions from paddock selection, cultivar choice, sowing method through to timing of herbicide control relate to meeting change certification requirements. I would therefore strongly recommend that any grower contemplating cultivar change obtain a current MAF Quality Management Field and Laboratory handbook and seek advice from a competent independent source on how these requirements affect his approach to the growing of his first crop.

\section{Pre-planting decisions}

\section{Paddock selection}

The main certification criteria are five years without clover sowings (MAF requirement) and pre-crop control of difficult weeds such as yarrow, docks and fieldmadder, while ensuring that problem chemical residues are not present. Therefore, many paddock decisions in relation to the intended future crop frequently start 3-4 years prior to sowing. Ensuring paddocks are level to provide uniform crop drilling and harvesting, and that other cultivars to be taken for seed in the same year are more than $50 \mathrm{~m}$ away assume greater importance prior to sowing.

\section{Clover cultivar choice}

More than 30 white clover cultivars are currently available from a range of companies. These cultivars are all vying for crop area and it is important to relate cultivar type to your soils and management options. Of equal requirement is a knowledge of their practical consistent seed yield and likely duration in the market place. In general, small-leaved cultivars grow better on heavy soils while large-leaved cultivars are required to cover the ground on lighter soils.

\section{Seed company choice}

Greatest success is gained when grower contractual obligations to the company are shared. The company's commitment to crop management through regular grower-related visits is important in giving both understanding and confidence. Seed availability, when ready to sow, is critical to this relationship to maximise autumn growth. Finally, grower commitment should be recognised through financial returns and consistent yearto-year cultivar seed supply.

\section{Paddock preparation}

Paddock leveling is initiated during cultivation of the previous crop, particularly if direct-drilling is contemplated (the preferred method).

If cultivation is required prior to sowing, use the shallowest possible cultivation to minimise bringing additional buried seed into the germinating soil zone. This can also be used as a final levelling process. Incorporate Treflan (trifluralin) herbicide at final working. Heavy roll and irrigate as required for uniformity of sowing depth and moisture needs for quick germination.

\section{Paddock fertility}

Soil test each paddock for phosphorus, potassium and sulphur after last working, or after crop removal prior to direct drilling. Where possible, apply any fertiliser 
needed in the row at drilling to minimise fertilising weeds between rows, or autumn broadcast after the clover is well established.

\section{Planting the crop}

\section{Seeding rate}

If in doubt a sowing rate of $3 \mathrm{~kg} / \mathrm{ha}$ is recommended. The requirement is to have good even rows over the whole crop.

\section{Drilling}

Row-spacings should be either $30 \mathrm{~cm}$ or $45 \mathrm{~cm}$ depending on soil type and cultivar chosen. Note that alternative spacings between $30 \mathrm{~cm}$ and $45 \mathrm{~cm}$ cannot be accommodated by most inter-row spraying machinery. Ensure space between drill runs is slightly wider than the row-spacing to eliminate possible loss of outside rows during inter-row spraying. If the paddock has slight undulations, drill across them to promote an evenness of sowing depth (establishment uniformity) and efficient harvesting. Drill the paddock up and down leaving four or five drill widths for turning at each end.

\section{Fertiliser and insecticide}

Apply fertiliser at planting if needed, depending on paddock fertility and earliness of sowing. All crops should be sown with a grass grub protectant in the row.

\section{Companion crop}

A low seeding of ryegrass in the row can have a range of advantages, depending on the site. These act as a protection from wind blow and frost heave, can provide a micro-climate for added growth, some weed suppression, partial protection from broad-acre sprays, and as a last resort, they are an inter-row spraying guide where the battle with weeds is lost.

\section{Sowing date}

Sow as early as possible from January onwards. Maximising the autumn-growth period advantages the future crop management options available.

\section{Crop management}

\section{Grazing}

Some grazing of early established crops can be beneficial depending on the cultivar. Don't over-graze as this can limit stolon development and final seed yield.

\section{Weed control and inter-row spraying}

Identify the weed species early, assess herbicide alternatives, weed spectrum controlled, growth stage requirements and additive needs.
The new herbicide Preside ( $800 \mathrm{~g} / \mathrm{kg}$ flumetsulam), and the possible registration of Jaguar $(25 \mathrm{~g} / \mathrm{l}$ diflufenican $+250 \mathrm{~g} / \mathrm{l}$ bromoxynil) should allow control of a wide range of previously hard-to-control weeds in white clover crops. For hard-to-kill grasses, a June-July application of Kerb (propyzamide), gives good results where litter is not present.

Usually $95 \%$ of cultivar-change crops require interrow spraying. It is very important to plan well ahead. If using a contractor, book him well ahead and keep him up-to-date so that the crop is sprayed at the best time.

Timing varies in relation to crop development and the requirement for inter-row removal of weeds not controlled by broadacre sprays. Note must be taken, however, of the certification requirement to have autumn-sown crops in a suitable condition for inspection by August 1 . Heavy rolling prior to inter-row spraying is a must, as is clean foliage to ensure good herbicide uptake.

\section{Spring management}

A final heavy rolling is critical to bed-down soil lifted by inter-row disc machines and/or worm casts. Both conditions, if untreated, can create significant seed losses at dressing due to similar sized soil particles in the seedline.

Apply nitrogen in the spring if needed to gain satisfactory ground cover at flowering, and monitor the crop for aphids and other sucking pests. Treat these with Maverik (taufluvalinate) if required.

\section{Pollination}

Beehives need to be sited as close to the crop as possible for greatest effect. The site should give protection from prevailing north-east and southerly winds. Stock at a rate of one beehive per two hectares of crop. I have noted that cooler than normal springs tend to affect later hive vigour. When bees have had plenty of early forage in the form of gorse and brassica crops, the clover has always yielded better than expected.

\section{Harvesting methods}

Spray with Preglone (1.0:0.6 paraquat/diquat) when most of the seed is yellow in colour, and harvest 7-10 days later. Some flexibility is available, but not at an unacceptable loss to clover yield.

Direct harvesting is the safest method in my opinion. Success is dependent on levelness of paddock and weather conditions. My clover harvests tend to conflict with those for cereals, either immediately before or after. Therefore minimum time for header alteration is critical to efficiency. I consider conventional methods 
of crop dessication with Reglone (diquat), mowing, then retrieval with a Murphy pickup to be too risky. I have modified (lowered) my header front to allow direct heading of the dessicated crop and this keeps most seedheads above cutter-bar height. Having earlier practiced good weed control, gives good header efficiency and a quick low seed-loss dressing capability.

\section{Conclusions}

- I count clover as one of my safest crops

- Every paddock and season is different, requiring management flexibility.

- Timing is the critical function of success.

- Early planting is the prime determinant of success.

- Clean crops give good header and dressing yields.

- Most of this information has been gained through personal experience.

I would hope that future first-time change growers gain more support from companies than that available to me in the early years of cultivar-change regulations. 
